\title{
Monitoring of Residual Forest Ecosystems Dynamics in the Mono Biosphere Reserve (Southeast Togo)
}

\author{
Gbétey Kokouvi Akpamou'1,2*, Yawo Konko³, Kouami Kokou1 \\ ${ }^{1}$ Laboratory of Forest Research, Faculty of Sciences, University of Lome, Lome, Togo \\ ${ }^{2}$ Ministry of Environment and Forest Resources, Lome, Togo \\ ${ }^{3}$ National Agency of Environment Management, Lome, Togo \\ Email: ${ }^{\star}$ fazzakpamou@gmail.com
}

How to cite this paper: Akpamou, G.K., Konko, Y. and Kokou, K. (2021) Monitoring of Residual Forest Ecosystems Dynamics in the Mono Biosphere Reserve (Southeast Togo). Natural Resources, 12, 271-289. https://doi.org/10.4236/nr.2021.129020

Received: August 9, 2021

Accepted: September 25, 2021

Published: September 28, 2021

Copyright (C) 2021 by author(s) and Scientific Research Publishing Inc. This work is licensed under the Creative Commons Attribution International License (CC BY 4.0).

http://creativecommons.org/licenses/by/4.0/ (cc) (i) Open Access

\begin{abstract}
The forest ecosystems of the Lacs 2 commune (South-East, Togo) are undergoing severe degradation, which has not yet been documented. This study is carried out in order to assess and quantify the spatio-temporal dynamics of residual forests and to identify the determinants of deforestation in South East Togo. The methodological approach is based on the use of historical aerial photographs from 1976 and drone images from 2019 in addition to field investigations. Several spatial structure indices were also calculated in order to quantify the fragmentation of classes and of the forest landscape. The results show that the forest landscape is changing. The classes of forests, plantations and palm groves show an annual rate of decline of $7.5 \%, 0.8 \%$ and 9.4\% respectively while the classes of savannahs, agglomerations, surface water and swamps increased by $16.4 \%, 0.4 \%, 0.7 \%$ and $0.1 \%$. The results also reveal a high fragmentation within the forest, plantation, surface water and swamp class and moderate fragmentation for the savannah and palm trees classes. At the landscape level, the savannah class is dominant by more than $70 \%$, thus making the landscape little diversified from an ecological point of view. The main driver of deforestation in the study area remains shifting slash-and-burn agriculture. It is accentuated by the establishment of perennial oil palm crops, which has influenced the annual deforestation rate by $0.72 \%$.
\end{abstract}

\section{Keywords}

Residual Forest, Forest Fragmentation, Drone Image, Aerial Photographs, Geographic Information System, Landscape Ecology 


\section{Introduction}

Natural ecosystems and their biological wealth constitute a source of life for human populations who exploit them according to methods that ensure sustainable production [1]. Several strategies have been developed for the preservation of natural ecosystems. Among these strategies is the defence of state areas called protected areas with various status and community areas erected by local populations for subsistence or cultural purposes.

The main functions of natural forests are production functions, economic functions and socio-cultural functions [2] [3]. Despite the many services that forests provide today, several factors are contributing to their decline [4]. These include population growth, land clearing, wildfires, the uncontrolled expansion of dwellings, the erosion of beliefs in traditional representations of forests and the weak power of traditional chiefs and conservators of forest relics [5]. One of the most viable options for biodiversity conservation is the integration of community forest management into the protected area system.

The fragmentation of natural habitats plays a key role in the loss of resident biodiversity and today approximately $70 \%$ of the forest ecosystems in the world are located within one kilometer of a forest edge [6]. The unsuspected effects of this fragmentation of habitats are the fragmentation of large ecosystems into smaller plots as a result of human activities such as road construction and forest exploitation, agriculture or mining.

Under the effect of human activities, it is established that the forest cover at the global level is disappearing at an unsuccessful rate. Indeed, recent studies show a decline in terrestrial forest cover, which fell from 31.6\% in 1990 to $30.6 \%$ in 2015 [7]. The reality is even more alarming in the countries known to be forested and in the process of developing located in the tropics. Thus, during the same period, we note on all degraded lands in sub-Saharan Africa a loss of forest from $30.6 \%$ to $27.1 \%$ [7]. In West Africa and particularly in Togo, land-use change is resulting in deforestation and degradation of forest cover at a frantic and worrying rate [8]. The same phenomenon has been reported in Benin [9].

It is also noted that the mode of management of these conservation areas has been unilaterally and in a repressive manner by the forest administration in most cases, thus alienating the rights of local communities. This situation has hampered the application of regulatory texts governing the conservation of biological resources and caused a decline in forest areas due to human activities [10] [11] [12].

In order to correct this distortion and involve the populations in the conservation and management of forest resources, several policies, strategies and programs were developed until the introduction of the concept of Community Forests (CF) through the law No. 2008-009 of June19, 2008 on the Forestry Code which enshrines the taking into account of the concerns of local communities to manage, in a consensual manner with the forest administration, the domain of individuals by offering them the opportunity to benefit from all the benefits they 
can derive from it. FC's approach finds its effectiveness in the empowerment and empowerment of local communities to take charge of economic production activities to reduce poverty, improve living conditions and ensure local development [13].

Since the inscription of the Mono Biosphere Reserve (MBR) on the UNESCO heritage list in 2017, new conservation sites have been identified and deserve special attention with a view to updating the MBR websites. It, therefore, appears necessary to characterize the said sites grouped within the complex of community forests Amevo, Fontan, Mamboui, Dougbanave, Avelebe (AFOMADEAVE) in the Aveve terroir in south-eastern Togo.

The continuous degradation phenomenon observed in recent years within this complex raises fears of the risk of loss of residual forests and/or their conversion into long-term agricultural land if current cultivation practices continue [14]. The continued degradation of forest resources in south-eastern Togo results from a combination of many climatic and anthropogenic factors. Faced with such a complex issue, observation of forest landscapes over a period is necessary in order to assess the nature and extent of natural and anthropogenic processes for planning the sustainable management of natural resources in the area. The application of remote sensing, satellite imagery techniques is commonly used by management institutions nowadays for the analysis of forest ecosystem dynamics and land use mapping [14] [15] [16]. This study is being carried out to continue the assessments within the reserve and to provide the management authority, in particular the permanent secretariat of the MBR, with land use planning and management guidelines. It aims to determine the modifications of forest cover from a diachronic analysis of the types of land use within the AFOMADEAVE community forest complex in the Aveve region between 1976 and 2019 from aerial photographs and drone data.

\section{Study Area}

The study area is part of the lower valley of the Mono River and constitutes a portion of the Aveve area in the Lacs 2 commune, located to the south of the Mono Biosphere Reserve (RBM) in the south-east of Togo. It is a set of forest ecosystems covering an average area of approximately $3309.73 \mathrm{Ha}$, and is grouped within the complex of five (5) residual community forests named Amevo, Fontan, Mamboui, Dougbanave, Avelebe (AFOMADEAVE). It lies between latitudes $6^{\circ} 25^{\prime} 59.485^{\prime \prime}$ and $6^{\circ} 22^{\prime} 35.331^{\prime \prime}$ North and longitudes $1^{\circ} 43^{\prime} 46.77^{\prime \prime}$ and $1^{\circ} 46^{\prime} 38.464^{\prime \prime}$ East (Figure 1).

The topography is not very rugged and dominated by vast plains. The pedology is characterized by the class of little evolved soils, the class of vertisols and the class of soils with iron sesquioxides [17]. From a climatic point of view, the area benefits from the Guinean tropical regime characterized by an alternation of two rainy seasons and two well-marked dry seasons of unequal duration. The annual rainfall varies from 1000 to $1400 \mathrm{~mm}$ /year. The average temperature is generally high, and is around $27^{\circ} \mathrm{C}$ in the coastal zone [18]. 


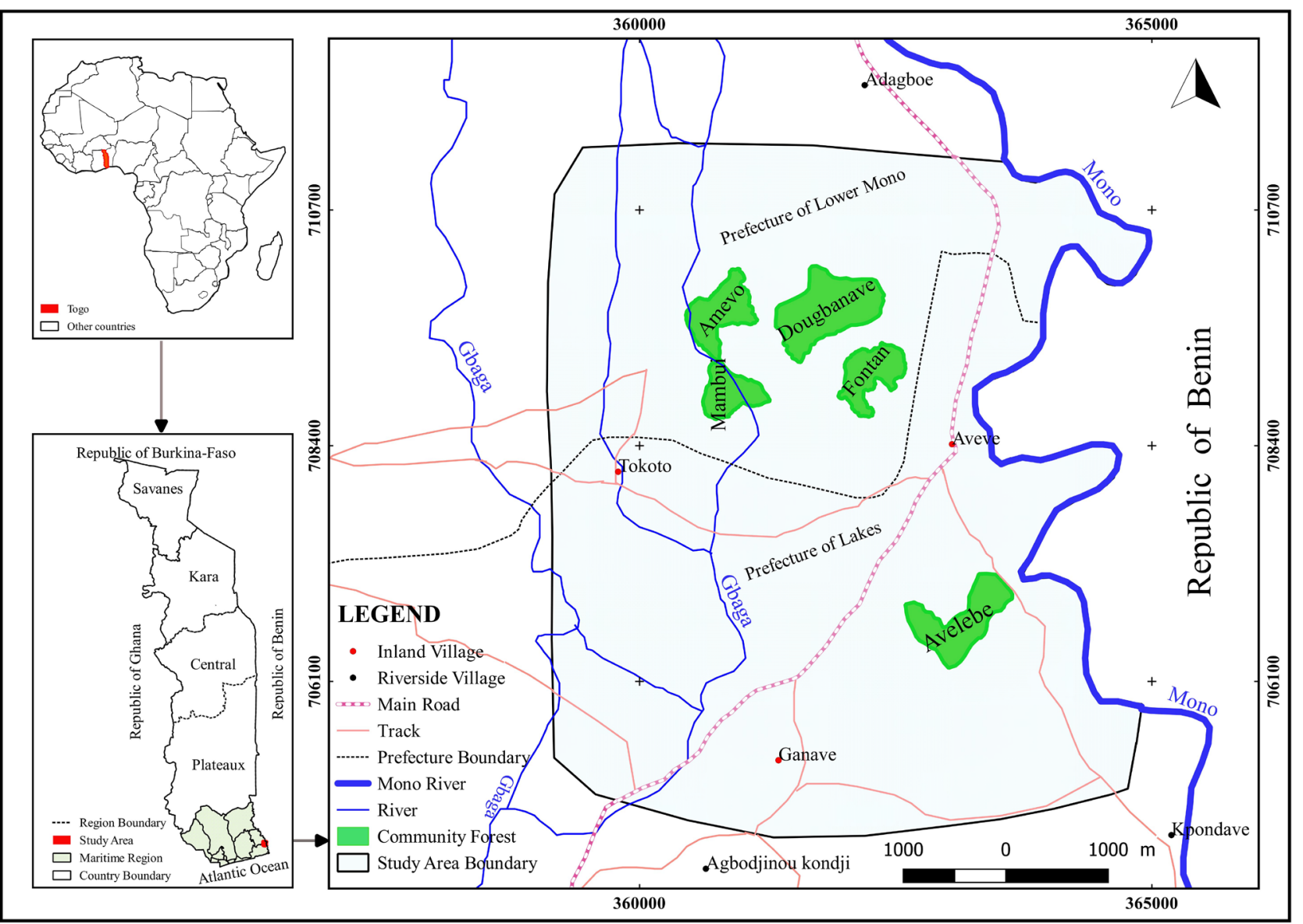

Figure 1. Localisation of study area.

\section{Materials}

\subsection{Drone Data}

The drone data was acquired on February 17, 2019 using a Swiss drone WingtraOne VTOL. This drone has medium size and provides very high spatial resolution images. In addition, it has the ability to cover a large area, allowing the identification of all residual forests in the landscape. It is equipped with high-performance 42-megapixel cameras taking panchromatic band images and RGB (Red, Green, Blue) images. It also uses a GPS system for geolocation. As part of this study, the flight protocol was pre-programmed and subsequently implemented. The camera model used is UMC-R10C_E15 mm F4.5_15.0_5456x3632 (RGB). The drone flew at an altitude of $614 \mathrm{~m}$ below the clouds. The duration of each flight varied between 15 and 30 minutes depending on weather conditions and battery life. The number of flights carried out is six (6) allowing the acquisition of 600 photos covering a total area of 3309.73 ha or $33.09 \mathrm{~km}^{2}$. The spatial resolution of the drone image is $18 \mathrm{~cm}$.

\subsection{Aerial Photography Data}

The historical aerial photographs were provided by the General Department of 
Cartography in Togo. These were historical photographs acquired during the period 1976-1985 through several aerial photography acquisition missions using aircraft using various optical chambers fitted with objectives of various focal lengths [19]. The copies of the saved negatives were pre-processed by the German office DFS (Deutsche Forest service Gmbh) and ortho rectified in 2017. There are 4503 pre-processed photographs covering $90 \%$ of the national territory. They are in panchromatic mode. The radiometric resolution is 8 bits and the spatial resolution is $50 \mathrm{~cm}$. For this study four (4) historical photographs (P1_350000-700000, P2_350000-710000, P3_360000-700000, P4_360000-710000) from 1976 covering the entire study area were used.

\section{Methodology}

\subsection{Data Pre-Processing}

The drone data was pre-processed under the dedicated Pix4D drone data processing software. These data have undergone the operations of calibration, construction of point clouds and construction of meshes. All the drone images were mosaicked at the same time, making it possible to avoid an Ortho mosaic [20] covering the entire study area. The product was subsequently enhanced allowing better discrimination of landscape features.

The historical aerial photographs have been sufficiently pre-processed by the German DFS office. For this reason, only the mosaicking and contrast enhancement operations were necessary. The mosaicking made it possible to link the four photographs of the study area into a single image [21] [22] covering the entire area of interest. The contrast enhancement was used to rebalance the contrasts and improve the quality of the images [23].

In order to harmonize spatial resolution for spatiotemporal analysis, drone images and historic aerial photographs were resampled to $25 \mathrm{~cm}$.

\subsection{Data Segmentation}

The drone images and historical aerial photographs were segmented under the eCognition software. This operation consists of an automatic subdivision of the images into small homogeneous regions through the creation of segments [19]. The data has been segmented on the basis of certain statistical parameters. Starting from a pixel considered being the smallest object in an image, neighboring pixels are analyzed on the basis of their local homogeneity criteria and gathered as a group of pixels. During this process, segments in shapefile format are formed according to the criteria of spectral and spatial homogeneity.

\subsection{Interpretation and Classification of Data}

The drone images and historical aerial photographs were interpreted visually under QGIS software after defining an interpretation key. For this study, the interpretation key used for the first national forest inventory and for the classification of historical aerial photographs [19] was adopted with some modifications. 
The classification of the data was carried out by assigning the segments resulting from the segmentation operation to the land use units on the basis of the interpretation key. To do this, the original image and the layer comprising the segments are overlay and the interpreter assigns the classes to the corresponding segments.

\subsection{Spatio-Temporal Analysis}

Spatio-temporal analysis for monitoring the dynamics of residual forest ecosystems was carried out on the basis of the annual rate of spatial change (Tannual) [14]. The calculation of this rate is repeated in Equation (1). $S_{1}$ and $S_{2}$ represent respectively the areas for the year $2019\left(A_{2}\right)$ and the year $1976\left(A_{1}\right)$ corresponding to the exact dates of acquisition of the satellite images respectively for the first year and second year. A positive value indicates expansion while a negative value implies regression.

$$
T_{\text {anпuel }}=\left(S_{2}-S_{1}\right) /\left(A_{2}-A_{1}\right)
$$

The deforestation rate $(\theta)$ was calculated for the forest class and takes into account the cleared land and the standardized formula proposed by Puyravaud (2002) [24] was applied (Equation (2)).

$$
\theta=-100 /\left(A_{2}-A_{1}\right) \times \ln \left(S_{2} / S_{1}\right)
$$

\subsection{Fragmentation Indices by Land Use Units}

For the analysis of the fragmentations by class, three indices were retained according to their efficiency and their simplicity of implementation: Number of polygon per class $(\mathrm{Nj})$ [25], Average value of the area of the polygon by class (Ajmoy) [25], proportion of area occupied by the largest polygon or index of dominance $(\mathrm{Dj})$ [25]. $\mathrm{Nj}$ is the sum of the polygons $\left(a_{i}\right)$ for a class at a given date (Equation (3)). Fragmentation is maximum if the number of polygon is high and low if the number of tasks is less during the period considered. AjMoy is the ratio between the total area of the class (Atj) and $\mathrm{Nj}$ (Equation (4)). When the number of polygon is high, Ajmoy is low and indicates high fragmentation. $\mathrm{Dj}$ is the ratio of the maximum area of the largest polygon (AjMax) and the total area of the class (Atj) (Equation (5)). If the dominant polygon is very small, the fragmentation is very strong.

$$
\begin{gathered}
\mathrm{Nj}=\sum_{i=1}^{n} a_{i} \\
\mathrm{AjMoy}=\mathrm{Atj} / \mathrm{Nj} \\
\mathrm{Dj}=\mathrm{AjMax} / \mathrm{Atj}
\end{gathered}
$$

\subsection{Landscape Fragmentation Indices}

The fragmentation of the landscape is analyzed through the Hill index [26] which combines both the Simpson diversity index $(1 / D)$ [27] and the Shannon-Wiener diversity index $(H)$ [28]. Choosing to use these three indices, 
Shannon Wiener, Simpson and Hill together allows for a more complete study of information about the structure and composition of the landscape. Several authors recommend their use [29] [30]. The calculations of the Shannon Wiener, Simpson and Hill indices are repeated respectively by Equations (6), (7) and (8). The closer the Hill index approaches to the value 1, the more the landscape is less diversified.

$$
\begin{gathered}
H^{\prime}=-\sum_{i=1}^{7} P_{i} \log \left(P_{i}\right) \\
1 / D=1 / \sum_{i=0}^{7} P_{i}^{2} \\
\text { Hill }=(1 / D) / \mathrm{e}^{H^{\prime}}
\end{gathered}
$$

\subsection{Method of Results Validation}

The results of spatial data processing only become truly reliable after validation carried out in the field (or with reference data) and when they are accompanied by relevant statistics and indicators of the quality of the results [31]. Within the framework of this study, 530 and 482 points were retained for the ground checks respectively for the data of 2019 and 1976. The distribution of points in the different classes of land use is made randomly with a constraint distance of $100 \mathrm{~m}$ between neighbouring points to avoid any correlation [32]. Following the field checks, two confusion matrices were produced (Table 1, Table 2).

The confusion matrix was used to calculate the various precision indicators deemed relevant, including overall precision, producer precision, user precision, F-score precision, commission and omission errors. These indicators were chosen because they are considered more relevant than the Kappa index for detailed validations of mapping products [33] [34] [35].

The overall accuracy (OA) indicates the percentage of well classified points compared to the total number of controlled points. It represents the ratio between the total number of correct points (O Correct Points) and the total number of controlled points (O Controlled points) [34]. The formula used for calcu-

\begin{tabular}{|c|c|c|c|c|c|c|c|c|}
\hline \multirow[b]{2}{*}{ Classes } & \multicolumn{8}{|c|}{ Ground truths } \\
\hline & Forest & Savannah & Palm groves & Plantation & $\begin{array}{l}\text { Agglomeration and } \\
\text { infrastructures }\end{array}$ & Water bodies & Swamps & Total \\
\hline Forest & 76 & 0 & 0 & 0 & 0 & 0 & 0 & 76 \\
\hline Savannah & 0 & 60 & 0 & 0 & 0 & 0 & 0 & 60 \\
\hline Palm groves & 0 & 2 & 81 & 2 & 0 & 0 & 0 & 85 \\
\hline Plantation & 0 & 0 & 3 & 54 & 0 & 0 & 0 & 57 \\
\hline Agglomeration and infrastructures & 0 & 0 & 0 & 1 & 78 & 0 & 0 & 79 \\
\hline Water bodies & 0 & 0 & 0 & 0 & 0 & 69 & 3 & 72 \\
\hline Swamps & 0 & 0 & 0 & 0 & 0 & 2 & 51 & 53 \\
\hline Total & 76 & 62 & 84 & 57 & 78 & 71 & 54 & 482 \\
\hline
\end{tabular}
lating the $\mathrm{OA}$ is illustrated by Equation (9).

Table 1. Confusion matrix for 1976. 
Table 2. Confusion matrix for 2019.

\begin{tabular}{|c|c|c|c|c|c|c|c|c|}
\hline \multirow[b]{2}{*}{ Classes } & \multicolumn{8}{|c|}{ Ground truths } \\
\hline & Forest & Savannah & Palm groves & Plantation & $\begin{array}{l}\text { Agglomeration and } \\
\text { infrastructures }\end{array}$ & Water bodies & Swamps & Total \\
\hline Forest & 84 & 0 & 0 & 0 & 0 & 0 & 0 & 84 \\
\hline Savannah & 0 & 75 & 0 & 0 & 0 & 0 & 0 & 75 \\
\hline Palm groves & 0 & 1 & 78 & 1 & 0 & 0 & 0 & 80 \\
\hline Plantation & 0 & 0 & 3 & 86 & 0 & 0 & 0 & 89 \\
\hline Agglomeration and infrastructures & 0 & 0 & 0 & 0 & 79 & 0 & 0 & 79 \\
\hline Water bodies & 0 & 0 & 0 & 0 & 0 & 66 & 1 & 67 \\
\hline Swamps & 0 & 0 & 0 & 0 & 0 & 1 & 55 & 56 \\
\hline Total & 84 & 76 & 81 & 87 & 79 & 67 & 56 & 530 \\
\hline
\end{tabular}

Producer Accuracy (PA) is the probability for a point belonging to a class in the ground truth to be correctly classified. Unlike overall accuracy, this is an indicator of accuracy by class. It is calculated by making the ratio between the number of correct points in the ground truth column for a class (P Correct) and the total number of points checked for the same class column (P Controlled) [33]. Equation (10) shows the calculation of the PA. The complement of producer accuracy (1-PA) is error of omission [35].

$$
\mathrm{PA}=\frac{\text { P Correct }}{\text { P Controlled }}
$$

User Accuracy (UA) is also an indicator of accuracy by class. It is the probability for a point classified in a class on the map to really belong to that class on the ground. It represents the ratio between the number of correct points of the class line on the map ( $\mathrm{U}$ Correct) and the total number of points controlled for the same class line (U Controlled) [33]. The formula used to calculate the UA is illustrated by Equation (11). The complement of user accuracy (1-UA) is the commission error [35].

$$
\mathrm{UA}=\frac{\mathrm{U} \text { Correct }}{\mathrm{U} \text { Controlled }}
$$

F-Score accuracy (FSA) is the summary indicator of user precision and producer accuracy to assess the performance of the processing method [31]. It is given by the geometric mean of the producer accuracy and the user accuracy (Equation (12)).

$$
\mathrm{FSA}=\frac{\mathrm{PA}+\mathrm{UA}}{2}
$$

\section{Results}

\subsection{Historical State of Forest Ecosystems}

In 1976 , the study area was mainly covered with savannah $(75.10 \%$ of the total 
area), followed by forests (11.02\%), palm groves (7.66\%), water body (3.99\%), agglomeration and infrastructures $(1.07 \%)$, swamps $(0.76 \%)$, plantations (eucalyptus and teak, $0.40 \%$ ) (Figure 2(a), Table 3). Two (2) types of formations characterize the Aveve area in 1976. These are mainly savannas with Mitragyna

Table 3. Statistics of land cover changes for the period 1976-2019.

\begin{tabular}{|c|c|c|c|c|c|c|}
\hline & 1976 & 2019 & 1976 & 2019 & \multirow{2}{*}{$\begin{array}{c}\text { 2019-1976 (S2-S1) } \\
\text { Rate of spatial } \\
\text { change }(\%)\end{array}$} & \multirow{2}{*}{$\begin{array}{c}\text { Annual rate of } \\
\text { spatial change } \\
\mathrm{T}_{\text {annuel }}(\%)\end{array}$} \\
\hline Classes & \multicolumn{2}{|c|}{ Area (Ha) } & \multicolumn{2}{|c|}{ Area (\%) } & & \\
\hline Forest & 364.86 & 267.81 & 12.068 & 8.858 & -3.210 & -0.075 \\
\hline Savannah & 2199.13 & 2412.77 & 72.738 & 79.804 & 7.066 & 0.164 \\
\hline Palm groves & 253.62 & 131.82 & 8.389 & 4.360 & -4.029 & -0.094 \\
\hline $\begin{array}{l}\text { Plantation } \\
\text { (eucalyptus, teak) }\end{array}$ & 13.36 & 2.72 & 0.442 & 0.090 & -0.352 & -0.008 \\
\hline $\begin{array}{l}\text { Agglomeration and } \\
\text { infrastructures }\end{array}$ & 35.34 & 40.48 & 1.169 & 1.339 & 0.170 & 0.004 \\
\hline Water bodies & 131.97 & 141.01 & 4.365 & 4.664 & 0.299 & 0.007 \\
\hline Swamps & 25.09 & 26.76 & 0.830 & 0.885 & 0.055 & 0.001 \\
\hline Total & 3023.37 & 3023.37 & 100.000 & 100.000 & & \\
\hline
\end{tabular}

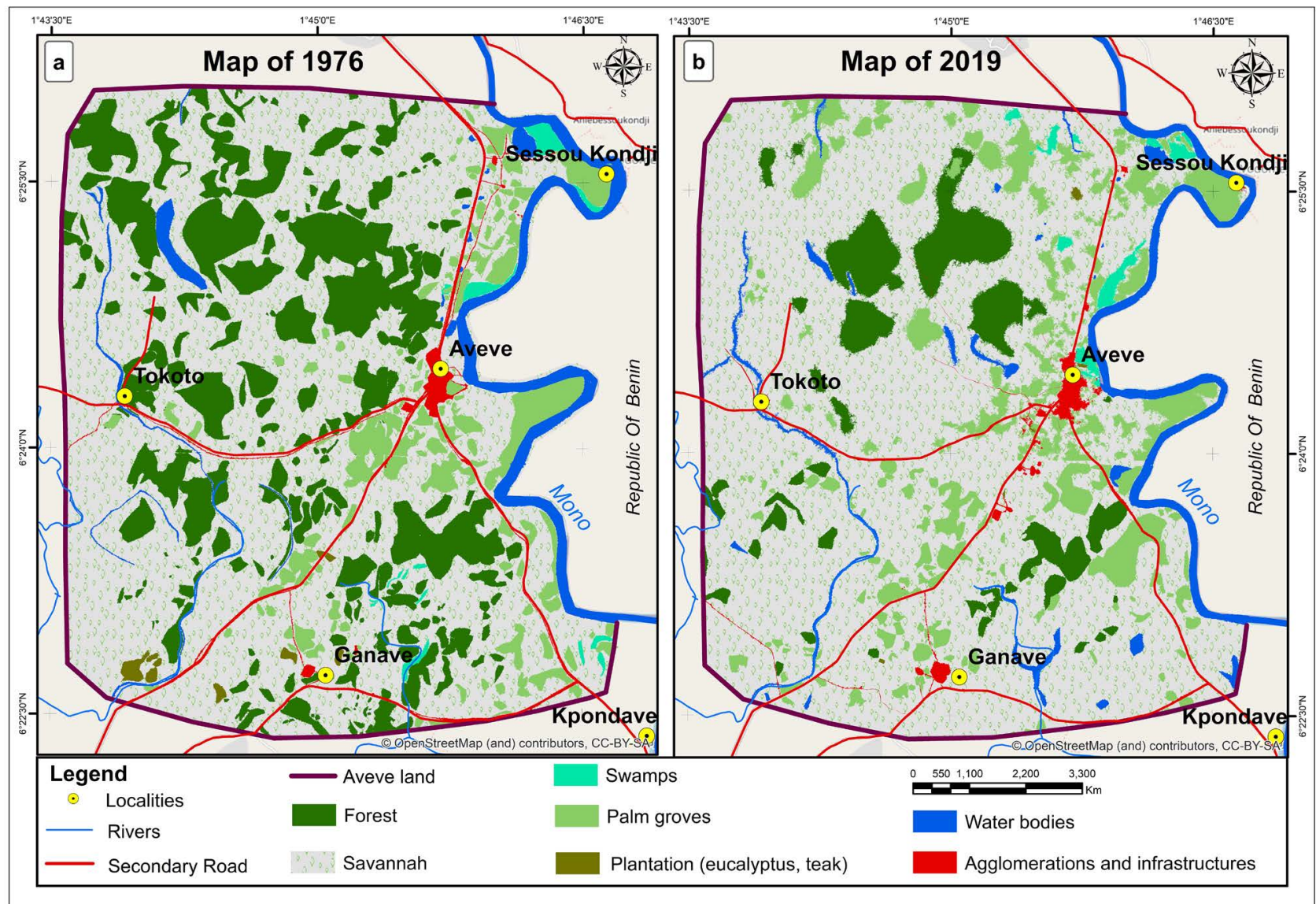

Figure 2. Land use/land cover change. (a) Map of land use/land cover in 1976; (b) Map of land use/land cover in 2019. 
inermis species (75.10\%) and dry forests and gallery forests (11.02\%). The palm groves, the main economic sources in the area, were mainly located along the main roads and around the agglomeration. Surface water was located in depressions and natural drainage channels that periodically regulated the floods of the Mono River.

\subsection{Current State of Residual Forest Ecosystems}

In 2019 , the study area is characterized by the forest (8.8\%), savannah (79.8\%), plantations $(0.09 \%)$ and palm groves $(4.36 \%)$ classes. The other identified classes consist of agglomerations (1.34\%) of water bodies (4.66\%) and swamps $(0.88 \%)$ (Figure 2(b), Table 3). Due to the pressures exerted on forest area, several islands of forests, including gallery forests, have disappeared or are in a state of severe degradation. The dominant formations are the tree and shrub savannahs which constitute the main matrix within which we can distinguish the islands of forests and much degraded gallery forests. There are two large blocks of residual forests resulting from the advance of the agricultural front, the complex of four islands of community forests located at the west of the Aklakou-Batonou road axis and another community forest located at the east in the bed of the Mono River within the Mitragyna inermis species swamps.

All these forests are under the influence of demographic pressure and food crops and are constantly inundated by the floods of the Mono or by the rainwater that plows the river horses of the Mono.

\subsection{Spatio-Temporal Evolution of Residual Forest Ecosystems}

From 1976 to 2019, the landscape recorded profound spatial changes. Forests, plantations and palm groves declined while other classes experienced spatial expansion. Regarding forests, there was a loss of 97.1 ha, which represents a decrease of $3.2 \%$ in area over the 43 years. The calculated deforestation rate is $0.72 \%$. Over the same period, the regression rates observed for the palm groves and plantations classes are $4.01 \%$ and $0.35 \%$ respectively. On the other hand, for the other classes, they recorded relatively weak expansions with the exception of the savannas which experienced an expansion rate of around 7.1\% (Figure 2).

\subsection{Classes Fragmentation}

Table 4 below summarizes the values for the indices $\mathrm{Nj}$, Ajmoy and $\mathrm{Dj}$ of the spots in the different land use classes of the area studied. The number of polygon, average polygon area and dominance were calculated. It can be seen that the number of polygon has decreased for the forest, plantation, water bodies and swamp classes. On the other hand, savannahs and palm groves has increased. These results reveal a high level of fragmentation and disappearance of patches within the forest, plantation, water body and swamp class, while the savannah and palm groves classes are very slightly fragmented. For the agglomeration class, although the number of patches is decreasing, it is not a fragmentation but 
Table 4. Classes fragmentation index.

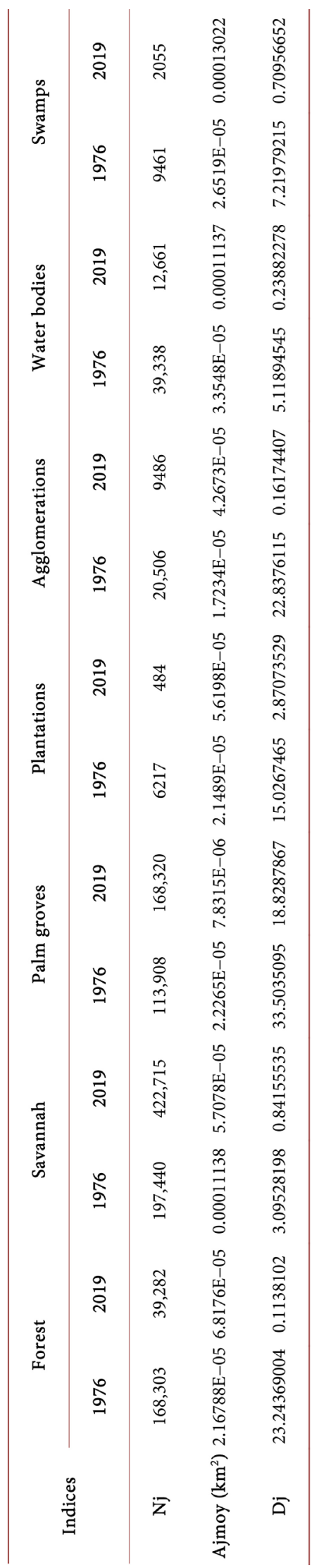


rather an aggregation of patches due to the development of agglomeration and villages. This is confirmed by the average area of the polygon of the agglomeration class which has an increasing trend from 1976 to 2018.

For the average area of the patches per class, the values obtained are all relatively low, indicating a fragmentation in all the classes. The degree of fragmentation observed is variously assessed with regard to the low values obtained during the two dates.

With regard to the dominance index, the average area of largest polygon has experienced a significant regression at the level of all classes. For example, in 1976, the average area of largest polygon of the forest class occupied $23.24 \%$ while in 2019 it was $0.11 \%$. In general, these results confirm the largest polygon area regression trend within all the classes identified in the forest ecosystem of the area between 1976 and 2019. In addition, for each observation date, the observed fragmentation varies within each class and between classes (Table 4).

\subsection{Landscape Fragmentation}

At the landscape level, the values of the Hill Synthesis Index are slightly greater than 1 indicating low landscape diversity. This index takes into account the Shannon diversity index which expresses the diversity by taking into consideration the number of classes and the abundance of spots and the Simpson index which measures the probability that two spots selected at random belong to the same class (Table 5). In our context, the savannah class represents the landscape matrix with a proportion greater than $70 \%$ for the two dates. It follows that the landscape is not very diversified from a spatial point of view.

\subsection{Results Occuracy}

The results of the map were validated using ground data and the confusion matrix. Table 6 and Table 7 show the various accuracy indicators calculated from the confusion matrix. The overall accuracy $(\mathrm{OA})$ of the results obtained is of the order of $97.30 \%$ for the 1976 year and $98.67 \%$ for the year 2019. For all the land use class, the producer accuracy (PA) and the user accuracy (UA) are greater than $90 \%$. F-Score accuracy (FSA) or geometric means between the PA and UA are higher than $90 \%$, indicating a strong approximation of the values of the map and the values of the ground. Omission and commission errors are low. It follows from these accuracy indicators that the analysis method is good and that the results are reliable and can be made available to decision-makers or users for using.

Table 5. Landscape fragmentation index.

\begin{tabular}{ccc}
\hline Indices & 1976 & 2019 \\
\hline $1 / D($ Simpson) & 1.81 & 1.54 \\
$H^{\prime}$ (Shannon) & 0.41 & 0.34 \\
Hill & 1.20 & 1.10 \\
\hline
\end{tabular}


Table 6. Accuracy indicators for 1976.

\begin{tabular}{|c|c|c|c|c|c|}
\hline \multirow[b]{2}{*}{ Classes } & \multicolumn{5}{|c|}{ Accuracy Indicators (1976) } \\
\hline & $\begin{array}{c}\text { Producer } \\
\text { Accuracy (\%) }\end{array}$ & $\begin{array}{c}\text { User } \\
\text { Accuracy (\%) }\end{array}$ & $\begin{array}{c}\text { F-Score } \\
\text { Accuracy (\%) }\end{array}$ & $\begin{array}{l}\text { Omission } \\
\text { Error (\%) }\end{array}$ & $\begin{array}{c}\text { Commission } \\
\text { Error (\%) }\end{array}$ \\
\hline Forest & 100.00 & 100.00 & 100.00 & 0.00 & 0.00 \\
\hline Savannah & 96.77 & 100.00 & 98.39 & 3.23 & 0.00 \\
\hline Palm groves & 96.43 & 95.29 & 95.86 & 3.57 & 4.71 \\
\hline $\begin{array}{l}\text { Plantation } \\
\text { (eucalyptus, teak) }\end{array}$ & 94.74 & 94.74 & 94.74 & 5.26 & 5.26 \\
\hline $\begin{array}{l}\text { Agglomerations } \\
\text { and infrastructures }\end{array}$ & 100.00 & 98.73 & 99.37 & 0.00 & 1.27 \\
\hline Water bodies & 97.18 & 95.83 & 96.51 & 2.82 & 4.17 \\
\hline Swamps & 94.44 & 96.23 & 95.34 & 5.56 & 3.77 \\
\hline Overall Accuracy = & $0 \%$ & & & & \\
\hline
\end{tabular}

Table 7. Accuracy indicators for 2019.

\begin{tabular}{|c|c|c|c|c|c|}
\hline \multirow[b]{2}{*}{ Classes } & \multicolumn{5}{|c|}{ Accuracy Indicators (2019) } \\
\hline & $\begin{array}{c}\text { Producer } \\
\text { Accuracy (\%) }\end{array}$ & $\begin{array}{c}\text { User } \\
\text { Accuracy (\%) }\end{array}$ & $\begin{array}{c}\text { F-Score } \\
\text { Accuracy (\%) }\end{array}$ & $\begin{array}{l}\text { Omission } \\
\text { Error (\%) }\end{array}$ & $\begin{array}{l}\text { Commission } \\
\text { Error (\%) }\end{array}$ \\
\hline Forest & 100.00 & 100.00 & 100.00 & 0.00 & 0.00 \\
\hline Savannah & 98.68 & 100.00 & 99.34 & 1.32 & 0.00 \\
\hline Palm groves & 96.30 & 92.86 & 94.58 & 3.70 & 7.14 \\
\hline $\begin{array}{l}\text { Plantation } \\
\text { (eucalyptus, teak) }\end{array}$ & 98.85 & 93.48 & 96.16 & 1.15 & 6.52 \\
\hline $\begin{array}{l}\text { Agglomeration and } \\
\text { infrastructures }\end{array}$ & 100.00 & 98.75 & 99.38 & 0.00 & 1.25 \\
\hline Water bodies & 98.51 & 97.06 & 97.78 & 1.49 & 2.94 \\
\hline Swamps & 98.21 & 94.83 & 96.52 & 1.79 & 5.17 \\
\hline
\end{tabular}

\section{Discussion}

\subsection{Determinants of the Degradation of Residual Forest Ecosystems}

The results revealed significant mutations of regressive tendency in the different classes of land use including forests, palm trees and plantations with a respective rate of change of $3.21 \%, 4.03 \%$ and $0.35 \%$ for the period 1976-2019. Regarding the residual forests, the number of polygon $(\mathrm{Nj})$ decreased from 168,303 (1976) to 39,282 (2019) representing a reduction rate of $77 \%$. This decrease is explained by the complete disappearance of some patches of forests. Figure 3 below perfectly illustrates the phenomenon of forest regression and fragmentation. Figure 3(a) is a view of a forest on aerial photograph in 1976 while Figure 3(b) and 


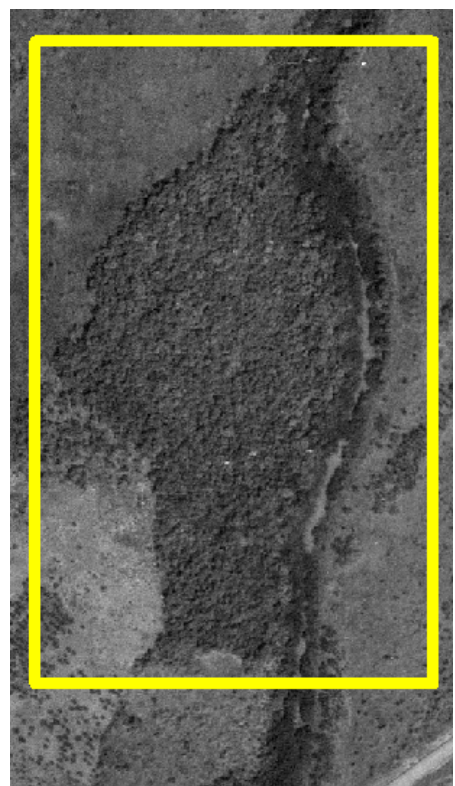

(a)

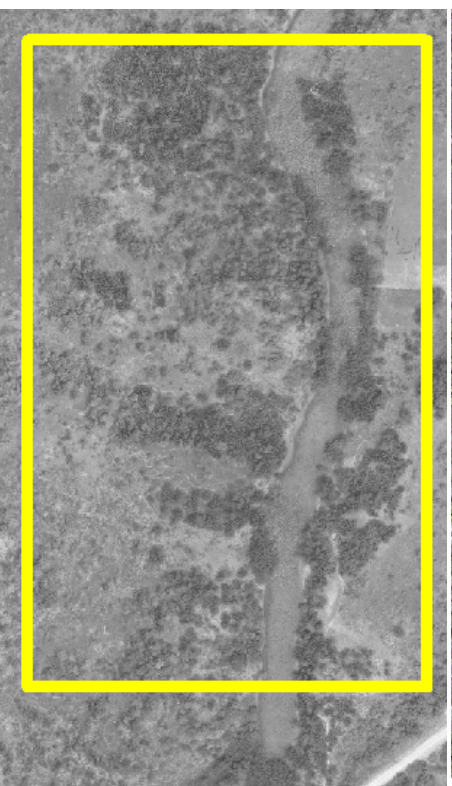

(b)

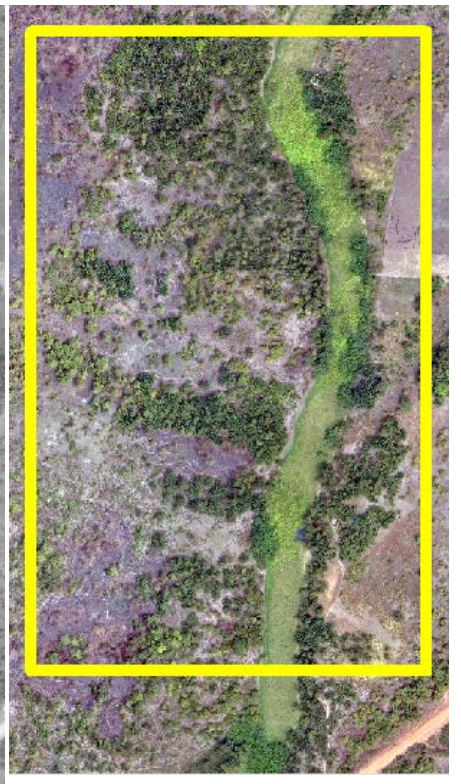

(c)

Figure 3. Regression and fragmentation of residual forests by diachronic analysis of aerial photographs from 1976 and drone images from 2019. (a) View of a forest on aerial photograph in 1976. (b) Overview of the same forest on panchromatic drone image in 2019. (c) Overview of the same forest on RGB drone image in 2019.

Figure 3(c) are Overview of the same forest on panchromatic and RGB drone image in 2019 respectively.

The average area of patch (Ajmoy) for the forest class in 2019 increased within this class due to the decrease in the number of polygon compared to 1976. This expresses the fragmentation of the forest class. This finding confirms not only the fragmentation of forests in the area but also the complete disappearance of some islets implying an annual deforestation rate of $0.72 \%$. For the dominance index $(\mathrm{Dj})$, the average class area experienced a significant regression in terms of the forest class, which went from $23.24 \%$ (1976) to $0.11 \%$ (2019). These results confirm the regression trend of forest ecosystems through the process of fragmentation and disappearance of forest islands. Several authors have also discussed the same regression trends in forest ecosystems in the sub-region [36] [37] [38].

This situation is due to unsustainable agricultural practices, themselves caused in the framework of our study area by increasing demographic pressure, the reduction of fallow times and slash-and-burn agriculture and the uncontrolled grazing. The trend towards deforestation and fragmentation is also rooted in the irrational exploitation of forest resources through excessive cutting, uncontrolled hunting, the search for firewood and the production of charcoal. Over use of land is considered to be the main cause of degradation of vegetation cover and loss of biodiversity in most West African countries [39] [40]. According to [36], the erosion of ancestral beliefs strongly contributes to this phenomenon. Apart from these causes, natural phenomena in particular, floods, fires of vege- 
tation, contribute substantially to the fragmentation and decline of forest resources.

\subsection{Prospects for the Management and Restoration of Forest Landscapes}

The forest lands investigated belong to family communities. According to [1], one of the sustainable management methods of community spaces is the participatory and integrated approach with state supervision. The diachronic study aimed at identifying changes in land use is an opportunity to define tools to support political decision-making in the sustainable management of ecosystems in the area. The regressive trend in forest resources observed calls on the managers of these forest lands to develop an integrated management plan and sustainable use of the residual forests and the biodiversity resident therein. The options to be considered for AFOMADEAVE residual forests are the restoration of islets and inter-islet spaces, securing existing cores, assisted regeneration of flood-prone savannahs, development and enhancement of forest galleries and water resources, the development of compatible alternatives to conservation, the evaluation of flora and fauna resources through multi-resource inventories leading to the preparation of the registration for the AFOMADEAVE community forest complex into the site of the Mono Biosphere Reserve listed as a UNESCO heritage.

\subsection{Benefits of Using Drone Images and Historical Aerial Photographs to Monitor Residual Forest Ecosystems}

The use of satellites data for the management of forest resources enables planning management to be optimized. The results of this study show that the combination of the two types of data (aerial photography and drone images) offers the possibility of a better understanding of the evolution of the vegetation cover. From National Aeronautics and Space Administration (NASA) Landsat satellite data to freely available ESA (European Space Agency) Sentinel images, decision-makers now have a range of satellite data available for use. One of the limitations of these data is their low power for the identification of residual forest ecosystems with small areas. The use of drone images and aerial photographs then allows better identification of residual forests in the current context of degradation and alarming deforestation. Drones can also be of great interest for carrying out flora and fauna inventories, restoring forest ecosystems, monitoring reforestation work, monitoring defended areas, evaluating natural regeneration, monitoring pathological, vegetation fire monitoring [41].

The combination of the drone technique and aerial photography for monitoring the dynamics of residual forest ecosystems has led to conclusive results that should be used in the planning and monitoring of the sustainable management of the forest complex's resource AFOMADEAVE communities and extend it to other ecosystems in the west African sub-region. 


\section{Conclusion}

This study based on the combined use of aerial photography and high-resolution satellite imagery by drone revealed interesting results in the regressive dynamics of forest ecosystems in south-eastern Togo. In fact, over about 43 years, forests, palm groves and plantations have declined in favor of savannas, agglomeration and marshes. The determinants behind the strong degradation observed are the increasingly strong demand for fertile arable land and population growth. This trend of deforestation and the continued degradation of forest ecosystems is a major threat to resident biodiversity. These results show the urgency of adequate measures to be taken for the restoration of the residual forests of AFOMADEAVE.

\section{Acknowledgements}

We sincerely thank the coordination of the PALCC "support for the fight against climate change" project of the Ministry of the Environment and Forest Resources and the European Union delegation for funding the research work. Our thanks also go to the Happy-Togo association for the provision of the drone used for the campaign to fly over the territory of Aveve. We would also like to express our gratitude to all contributors for ensuring the quality of this article.

\section{Conflicts of Interest}

The authors declare no conflicts of interest regarding the publication of this paper.

\section{References}

[1] Maldague, M. (2004) Traité de gestion de l'environnement tropical. Tome I: Développement intégré des régions tropicales. Approche systémique, Notions, Concepts, Méthodes. Ecole Régionale Postuniversitaire d'Aménagement et de Gestion intégrés des Forêts et Territoires tropicaux, Republique démocratique du Congo, 18 p.

[2] Akouehou, G.S. (2004) Environnement institutionnel et gestion traditionnelle des espaces forestiers: Cas de la région des Monts Kouffé au Centre du Bénin. Les Cahiers d'Outre-Mer, 226-227. http://journals.openedition.org/com/526 https://doi.org/10.4000/com.526

[3] Akouehou, S.G., Djogbenou, C.P., Hounsounou, L.C., Goussanou A.C., Gbozo, E., Koutchade, A.C., Mensah, G.A. and Ganglo, C.J. (2012) Pratique des éclaircies dans les peuplements de teck de la Lama au Sud-Bénin, Fiche Technique N 6186. Bibliothèque National du Bénin.

[4] Glele, K.R., Akpona, T.J.D., Assogbadjo, A.E., Gaoue, O.G., Chakeredza, S., Gnangle, P.C., Mensah, G.A. and Sinsin, B. (2011) Ecological Adaptation of the Shea Butter Tree (Vitellaria paradoxa C.F. Gaertn.) along Climatic Gradient in Benin, West Africa. African Journal of Ecology, 49, 440-449. https://doi.org/10.1111/j.1365-2028.2011.01279.x

[5] Akouehou, S.G. (2003) Le territoire, les représentations sociales des espaces forestiers, la valorisation des coutumes et la gestion de la forêt classée des Monts Kouffé au Centre du Bénin. Colloque SAGERT, Montpellier, 17 p.

[6] Haddad, N.M., Brudvig, L.A., Clobert, J., Davies, K.F., Gonzalez, A., Holt, R.D., Lo- 
vejoy, T.E., Sexton, J.O., Austin, M.P., Collins, C.D. and Cook, W.M. (2015) Habitat Fragmentation and Its Lasting Impact on Earth's Ecosystems. Science Advances, 1, e1500052. https://doi.org/10.1126/sciadv.1500052

[7] FAO (2018) La situation des forêts du monde. Les forêts au service du développement durable. $158 \mathrm{p}$.

[8] Adjonou, K., Ali, N., Kokutse, A.D., Novigno, S.K. and Kokou, K. (2010) A Study of the Dynamics of Overexploited Natural Stands of Pterocarpus erinaceus Poir. (Fabaceae) in Togo. Bois et Forêts des Tropiques, 306, 45-56.

https://doi.org/10.19182/bft2010.306.a20431

[9] Agbanou, B.T. (2018) Dynamique de l'occupation du sol dans le secteur Natitingou-Boukombé (nord-ouest bénin): De l'analyse diachronique à une modélisation prospective. Thèse de Doctorat, Université Toulouse le Mirail-Toulouse II et Université nationale du Bénin, $271 \mathrm{p}$.

[10] Courcelaud, A. (2000) Forest Resources of the Togodo Wildlife Reserve (South Togo): Dynamics and Diagnosis of Participatory Management. Master Thesis, ENGREF, Montpellier.

[11] Kokou, K. (1998) Forest Mosaics in Southern Togo: Biodiversity, Dynamics and Human Activities. Doctoral Thesis, University of Montpellier II, Montpellier.

[12] Akpagana, K. (1989) Research on Dense and Humid Forests in Togo. Doctoral Thesis, University of Bordeaux III, Bordeaux.

[13] Lhoest, S., Fonteyn, D., Daïnou, K., Delbeke, L., Doucet, J.L., Dufrêne, M., Josso, J.F., Ligot, G., Oszwald, J., Rivault, E. and Verheggen, F. (2020) Conservation Value of Tropical Forests: Distance to Human Settlements Matters More than Management in Central Africa. Biological Conservation, 241, Article ID: 108351.

https://doi.org/10.1016/j.biocon.2019.108351

[14] Konko, Y., Rudant, J., Akpamou, G., Noumonvi, K. and Kokou, K. (2018) Spatio-Temporal Distribution of Southeastern Community Forests in Togo (West Africa). Journal of Geoscience and Environment Protection, 6, 51-65. https://doi.org/10.4236/gep.2018.67004

[15] Biaou, S., Houeto, F., Gouwakinnou, G., Biaou, S.S.H., Awessou, B., Tovihessi, S. and Tete, R. (2019) Dynamique spatio-temporelle de l'occupation du sol de la forêt classée de Ouénou-Bénou au Nord Bénin. Conférence OSFACO: Des images satellites pour la gestion durable des territoires en Afrique, Cotonou, Bénin, 21 p. https://hal.archives-ouvertes.fr/hal-02189367/document

[16] Mamane, B., Amadou, G., Barage, M., Comby, J. and Ambouta, J.M.K. (2018) Dynamique spatio-temporelle d'occupation du sol dans la Réserve Totale de Faune de Tamou dans un contexte de la variabilité climatique (Ouest du Niger). International Journal of Biological and Chemical Sciences, 12, 1667-1687. https://doi.org/10.4314/ijbcs.v12i4.13

[17] FAO (1997) Forest Resources Assessment, Tropical Countries. FAO Forestry Paper No. 112. Rome.

[18] MERF (2011) National Forest Action Plan of Togo-Phase1 (PAFN 1-TOGO) 2011-2019.

[19] DFS (2017) Interprétation de données historiques et conception d'un système national de suivi des forêts et d'un niveau de référence des forêts dans le cadre de la REDD+ au Togo, Projet de soutien à la préparation à la Réduction des Émissions dues à la Déforestation et à la Dégradation des forêts (REDD+). Ministère de l'Environnement et des ressources Forestières, Lomé.

[20] Agarwal, A., Singh, A.K., Kumar, S. and Singh, D. (2018) Critical Analysis of Classi- 
fication Techniques for Precision Agriculture Monitoring Using Satellite and Drone. 2018 IEEE 13 th International Conference on Industrial and Information Systems (ICIIS), Rupnagar, 1-2 December 2018, 83-88. https://doi.org/10.1109/ICIINFS.2018.8721422

[21] Konko, Y., Bagaram, B., Julien, F., Akpamou, K. and Kokou, K. (2018) Multitemporal Analysis of Coastal Erosion Based on Multisource Satellite Images in the South of the Mono Transboundary Biosphere Reserve in Togo (West Africa). OALib Journal, 5, 1-21. https://doi.org/10.4236/oalib.1104526

[22] Konko, Y., Okhimambe, A., Nimon, P., Asaana, J., Rudant, J. and Kokou, K. (2020) Coastline Change Modelling Induced by Climate Change Using Geospatial Techniques in Togo (West Africa). Advances in Remote Sensing, 9, 85-100. https://doi.org/10.4236/ars.2020.92005

[23] Konko, Y. (2016) Contribution of Remote Sensing and GIS to the Integrated Management of Community Forest Resources in the Bas-Mono Valley (South-East Togo). Master's Thesis, Post University Regional School of Integrated Management of Tropical Forests and Territories, Kinshasa, 94 p.

[24] Puyravaud, J.P. (2002) Standardizing the Calculation of the Annual Rate of Deforestation. Forest Ecology and Management, 177, 593-596. https://doi.org/10.1016/S0378-1127(02)00335-3

[25] McGarigal, K. and Marks, B.J. (1995) Spatial Pattern Analysis Program for Quantifying Landscape Structure. Gen. Tech. Rep. PNW-GTR-351. US Department of Agriculture, Forest Service, Pacific Northwest Research Station, 1-122. https://doi.org/10.2737/PNW-GTR-351

[26] Hill, M.O. (1973) Diversity and Evenness: A Unifying Notation and Its Consequences. Ecology, 54, 427-432. https://doi.org/10.2307/1934352

[27] Simpson, E.H. (1949) Measurement of Diversity. Nature, 163, 688-688. https://doi.org/10.1038/163688a0

[28] Shannon, C.E. and Weaver, W. (1949) The Mathematical Theory of Communication. University of Illinois Press, Urbana, 117 p.

[29] Peet, R.K. (1974) The Measurement of Species Diversity. Annual Review of Ecology and Systematics, 5, 285-307. https://doi.org/10.1146/annurev.es.05.110174.001441

[30] Routledge, R.D. (1979) Diversity Indices: Which Ones Are Admissible? Journal of Theoretical Biology, 76, 503-515. https://doi.org/10.1016/0022-5193(79)90015-8

[31] Konko, Y., Afelu, B. and Kokou, K. (2021) Potentialité des données satellitaires Sentinel-2 pour la cartographie de l'impact des feux de végétation en Afrique tropicale: Application au Togo. Bois et Forêts des Tropiques, 347, 59-75. https://doi.org/10.19182/bft2021.347.a36349

[32] Congalton, R.G. (1991) A Review of Assessing the Accuracy of Classifications of Remotely Sensed Data. Remote Sensing of Environment, 37, 35-46. https://doi.org/10.1016/0034-4257(91)90048-B

[33] Story, M. and Congalton, R.G. (1986) Accuracy Assessment: A User's Perspective. Photogrammetric Engineering and Remote Sensing, 52, 397-399.

https://www.asprs.org/wp-content/uploads/pers/1986journal/mar/1986_mar_397-3 99.pdf

[34] Rwanga, S.S. and Ndambuki, J.M. (2017) Accuracy Assessment of Land Use/Land Cover Classification Using Remote Sensing and GIS. International Journal of Geosciences, 8, 611-622. https://doi.org/10.4236/ijg.2017.84033

[35] Stehman, S.V. and Foody, G.M. (2019) Key Issues in Rigorous Accuracy Assessment 
of Land Cover Products. Remote Sensing of Environment, 231, Article ID: 111199. https://doi.org/10.1016/j.rse.2019.05.018

[36] Kokou, K., Caballe, G. and Akpagana, K. (1999) Floristic Analysis of Forest Patches in Southern Togo. Acta Botanica Gallica, 146, 139-144. https://doi.org/10.1080/12538078.1999.10515812

[37] Zoungrana, B.J., Conrad, C., Amekudzi, L.K., Thiel, M., Da, E.D., Forkuor, G. and Löw, F. (2015) Multi-Temporal Landsat Images and Ancillary Data for Land Use/Cover Change (LULCC) Detection in the Southwest of Burkina Faso, West Africa. Remote Sensing, 7, 12076-12102. https://doi.org/10.3390/rs70912076

[38] Tankoano, B., Hien, M., Dibi, N., Sanon, Z., Akpa, Y., Sokeng, V.J., Somda, I.J.I.J.O.I. and Studies, A. (2016) Cartographie de la dynamique du couvert végétal du Parc National des Deux Balé à l'Ouest du Burkina Faso [Mapping Land Cover Dynamics of Deux Balé National Park, Western Burkina Faso]. International Journal of Innovation and Applied Studies, 16, 83.

[39] Sawadogo, L., Tiveau, D. and Nygård, R. (2005) Influence of Selective Tree Cutting, Livestock and Prescribed Fire on Herbaceous Biomass in the Savannah Woodlands of Burkina Faso, West Africa. Agriculture, Ecosystems \& Environment, 105, 335-345. https://doi.org/10.1016/j.agee.2004.02.004

[40] Diallo, H., Bamba, I., Barima, Y.S.S., Visser, M., Ballo, A., Mama, A., Vranken, I., Maiga, M. and Bogaert, J. (2011) Effets combinés du climat et des pressions anthropiques sur la dynamique évolutive de la végétation d'une zone protégée du Mali (Réserve de Fina, Boucle du Baoulé). Science et changements planétaires/Sécheresse, 22, 97-107.

http://www.john-libbey-eurotext.fr/fr/revues/agro_biotech/sec/sommaire.md?type= text.html

[41] Fadil, S., Sebari, I., Bouhaloua, M. and El kadi, K.A. (2020) Opportunités d'utilisation de la technologie drone au niveau des écosystèmes forestiers. Revue Marocaine des Sciences Agronomiques et Vétérinaires, 8, 458-464. https://www.agrimaroc.org/index.php/Actes_IAVH2/article/view/888/1199 